\title{
Sporadic and genetic forms of paediatric somatotropinoma: a retrospective analysis of seven cases and a review of the literature
}

\author{
Cécile Nozières ${ }^{1 *}$, Pascale Berlier ${ }^{2}$, Clémentine Dupuis ${ }^{3}$, Catherine Raynaud-Ravni ${ }^{4}$, Yves Morel $^{5}$, \\ Françoise Borson Chazot ${ }^{1}$ and Marc Nicolino ${ }^{2}$
}

\begin{abstract}
Background: Somatotropinoma, a pituitary adenoma characterised by excessive production of growth hormone $(\mathrm{GH})$, is extremely rare in childhood. A genetic defect is evident in some cases; known genetic changes include: multiple endocrine neoplasia type 1 (MEN1); Carney complex; McCune-Albright syndrome; and, more recently identified, aryl hydrocarbon receptor-interacting protein (AIP). We describe seven children with somatotropinoma with a special focus on the differences between genetic and sporadic forms.
\end{abstract}

Methods: Seven children who presented in our regional network between 1992 and 2008 were included in this retrospective analysis. First-type therapy was somatostatin (SMS) analogues or transsphenoidal surgery. Control was defined as when insulin-like growth factor-1 (IGF-1) levels were within the normal range for the patient's age at 6 months after therapy, associated with decreasing tumour volume.

Results: Patients were aged 5-17 years and the majority $(n=6)$ were male. Four patients had an identified genetic mutation (McCune-Albright syndrome: $\mathrm{n}=1$; MEN1: $\mathrm{n}=1$; AIP: $\mathrm{n}=2$ ); the remaining three cases were sporadic. Accelerated growth rate was reported as the first clinical sign in four patients. Five patients presented with macroadenoma; invasion was noted in four of them (sporadic: $n=1$; genetic: $n=3$ ). Six patients were treated with SMS analogues; normalisation of IGF-1 occurred in one patient who had a sporadic intrasellar macroadenoma. Multiple types of therapy were necessary in all patients with an identified genetic mutation (4 types: $n=1 ; 3$ types: $n=2 ; 2$ types: $n=1$ ), whereas two of the three patients with sporadic somatotropinoma required only one type of therapy.

Conclusions: This is the first series that analyzes the therapeutic response of somatotropinoma in paediatric patients with identified genetic defects. We found that, in children, genetic somatotropinomas are more invasive than sporadic somatotropinomas. Furthermore, SMS analogues appear to be less effective for treating genetic somatotropinoma than sporadic somatotropinoma.

\section{Background}

Somatotropinoma is a pituitary adenoma characterised by excessive production of growth hormone $(\mathrm{GH})$ from the pituitary gland [1]. In adulthood, somatotropinoma is associated with severe symptoms, including organomegaly and dysmorphia [2], and diagnosis is usually delayed by six years after the initial presentation of symptoms [3].

\footnotetext{
* Correspondence: cecile.nozieres@chu-lyon.fr

'Fédération d'Endocrinologie du Pôle Est, Groupement Hospitalier Lyon Est, 69677, Bron, Cedex, France

Full list of author information is available at the end of the article
}

Somatotropinoma is rare in childhood and adolescence, and there is little literature on this topic. As in adults, diagnosis in children is delayed, but clinical presentation differs with accelerated growth being the first symptom observed after dysmorphic features [1].

Genetic defects have been recently identified in some somatotropinoma cases. These defects include multiple neoplasia syndromes, including the multiple endocrine neoplasia type 1 (MEN1) $[4,5]$, the Carney complex [6] and McCune-Albright syndrome [7]. Recently, mutations in the aryl hydrocarbon receptor interacting protein gene

\section{Biomed Central}


(AIP) were identified in some patients with familial isolated pituitary adenoma (FIPA) $[8,9]$. Such mutations account for $15 \%$ of FIPA kindreds and are associated with somatotropinomas, prolactinomas, non-secreting adenomas and rare cases of Cushing disease [10]. We present data on all children developing a somatotropinoma before 18 years of age between 1992 and 2008 in our regional network for the management of paediatric patients with endocrine disorders. Four of the children presented with a known genetic defect. The aim of this work was to analyse the clinical, biological, radiological and therapeutic aspects of these adenomas.

\section{Methods}

All children $(\mathrm{n}=7)$ with a GH-secreting pituitary adenoma that was diagnosed before 18 years of age in three hospitals in France [Lyon $(\mathrm{n}=5)$, Saint-Etienne $(\mathrm{n}=1)$ and Grenoble $(\mathrm{n}=1)$ ] were included in this analysis. One case was diagnosed in 1992 (when the patient was six years of age), and the other six cases were diagnosed between 2005 and 2008. We excluded patients with GHindependent gigantism, such as Beckwith-Wiedemann syndrome or Sotos syndrome, and patients with GHreleasing hormone secreting tumours.

A diagnosis of excessive production of GH was established by a high level of serum GH over 24 hours, not suppressible to $<1 \mu \mathrm{g} / \mathrm{L}, 180$ minutes after a $75 \mathrm{~g}$ oral glucose tolerance test, or a high insulin-like growth factor-1 (IGF-1) level for the patient's age.

Magnetic resonance imaging (MRI) was performed in six cases; images were analysed by the same radiologists. Invasiveness on MRI was assessed using the HardyVezina classification [11]. Tumours were considered as invasive when presenting with extrasellar expansion to the cavernous or sphenoidal sinus. For the oldest case, computed-tomography scanning was performed in 1992, and monitoring was done by MRI from 2000 onwards.

\section{Immunometric assay}

Serum GH levels were measured by radioimmunometric assay calibrated to the WHO 98/574 standard. Before 1995, the GH assay (for one patient) was performed using a polyclonal antibody kit.

Serum IGF-1 levels were measured using the IGF-1 RIACT kit (CIS Bio International). Results were presented as standard deviation (SD), adjusted for sex, age and pubertal stage. Prolactin was measured by radioimmunometric assay calibrated on 84/500 standard. Other hormones of the pituitary axis were also studied.

\section{Treatment protocol}

Somatostatin (SMS) analogues or transsphenoidal surgery were the first-type treatment, depending on each patient's clinical evolution and criteria. Patients received long-acting octreotide (10-30 mg) or lanreotide (30-120 $\mathrm{mg}$ ), managed by the patient's clinician, according to IGF-1 level and growth curve. Patients also received cabergoline at a dose of $0.5 \mathrm{mg}$ once to three times weekly.

Control was defined as when IGF-1 was within the normal range for the patient's age at six months after therapy, associated with a decreasing tumour volume of more than $30 \%$. SMS analogue resistance was defined in the present study as an IGF-1 level of more than +2 SD at six months when receiving the maximum dose of octreotide or lanreotide.

\section{Results}

Baseline clinical characteristics for the seven patients are presented in Table 1.

Four patients (patients 2, 3, 5 and 7) presented for a clinical consultation because of accelerated growth. (the growth curve for patient 5 is shown in Figure 1). The other patients presented for monitoring of McCune-Albright syndrome (patient 1), gynaecomastia (patient 4) or acquired resistance to cabergoline (patient 6). Acromegaly was diagnosed in patient 1 , three months after the onset of McCune-Albright syndrome, with macrocrania, a cardiac anomaly, enlarged hands and feet and nocturnal snoring. Patients 3 and 4 both presented with headaches and visual disturbances. Patient 6 had been treated with dopamine agonists for a macroprolactinoma since ten years of age and GH excess was suspected because of an acquired resistance to cabergoline, headaches and enlarged hands and feet. Only patients 2, 3 and 4 presented with a family history of pituitary adenomas (the family history of patients 3 and 4 is shown in Figure 2). Genetic analysis was positive for MEN1 in patient 2 (intron 3, c.765-6C-> T-splicing site) and AIP in patients 3 and 4 (exon 5, c.718T-> C- missense mutation), diagnosed at age 6,13 and 16 years of age, respectively. Extensive genetic analysis (MEN1, AIP, Carney) was negative in patients 5 and 7, who were diagnosed at five and nine years of age, respectively. MEN1 and AIP analyses were negative in patient 6 . MRI revealed an invasive macroadenoma with suprasellar and lateral extension to the cavernous sinus in patients $2,3,4$ and 6 , a noninvasive intrasellar macroadenoma in patient 5 and a microadenoma in patient 7 .

Therapeutic data for the seven patients are presented in Table 2 (FU: Follow-Up; C: Controlled; NC: Not Controlled).

Transsphenoidal surgery was the first-type therapy in patient 2 (presenting with visual defects due to chiasmatic compression) and patient 7 (presenting with a sporadic microadenoma). Patient 7 was cured but patient 2, with MEN1 and an invasive macroadenoma, remained uncontrolled despite multiple types of treatment (Table 2). Overall, six patients were treated with 
Table 1 Baseline clinical characteristics of patients with somatotropinoma

\begin{tabular}{lccccc}
\hline Patient & Sex & Date of diagnosis & Age at diagnosis (years) & Symptoms/reason for consultation & Size at diagnosis (SD) \\
\hline 1 & Male & $10 / 1992$ & 6.5 & Monitoring of McCune-Albright syndrome & Bone deformity, non-measurable size \\
\hline 2 & Female & $01 / 06 / 2007$ & 6.5 & Accelerated growth & +4 \\
\hline 3 & Male & $29 / 06 / 2005$ & 13 & Accelerated growth & +2 \\
\hline 4 & Male & $18 / 01 / 2006$ & 16.5 & Headaches, gynaecomastia & +3 \\
\hline 5 & Male & $16 / 03 / 2006$ & 5.5 & Accelerated growth & +4 \\
\hline 7 & Male & 2008 & 17 & Acquired resistance to cabergoline & $+0,5$ \\
\hline
\end{tabular}

SMS analogues; in 5 patients $(1,3,4,5$ and 6), this comprised first-type therapy. As shown in Figure 3, normalisation of IGF-1 occurred in only one case of sporadic intrasellar macroadenoma (patient 5). In this patient, an impressive tumoural response was observed with normalization of MRI after 33 months. In the other five cases, four of them being of genetic form, IGF-1 was not normalized, requiring additional types of therapy (3 types: $\mathrm{n}=1 ; 2$ types: $\mathrm{n}=2 ; 1$ type: $\mathrm{n}=1$ ).

At the end of treatment, four patients had normal IGF1 levels for their age, sex and pubertal stage (Figure 3, Table 2). Normalization of IGF-1 levels occurred in two

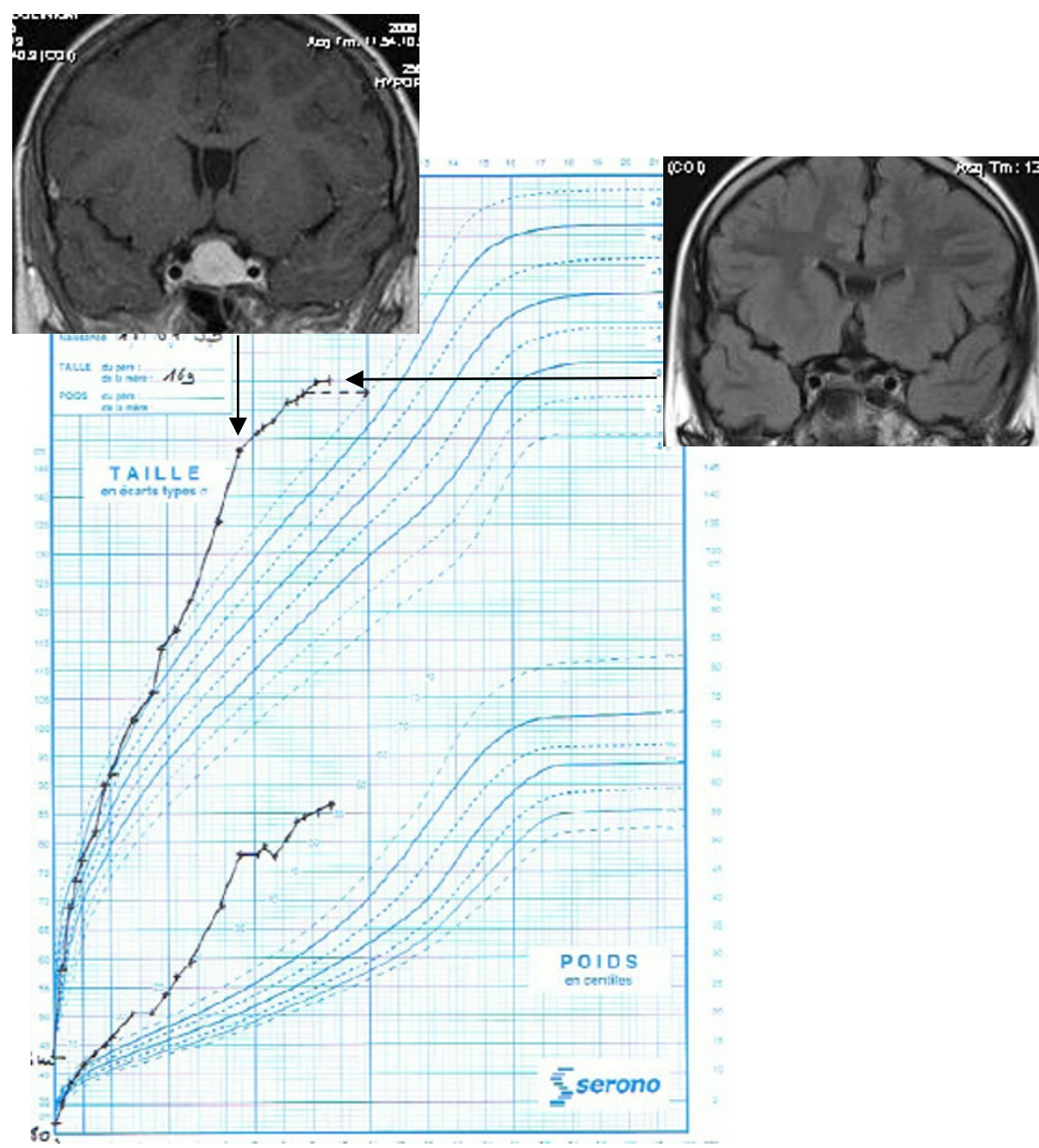

Figure 1 Growth curve of patient $\mathbf{5}$. At the time of diagnosis, magnetic resonance imaging (MRI) showed a non-invasive macroadenoma. Control was obtained with first-line somatostatin analogues. There was a correlation between decelerated growth, insulin-like growth factor-1 levels and disappearance of the macroadenoma on MRI. 


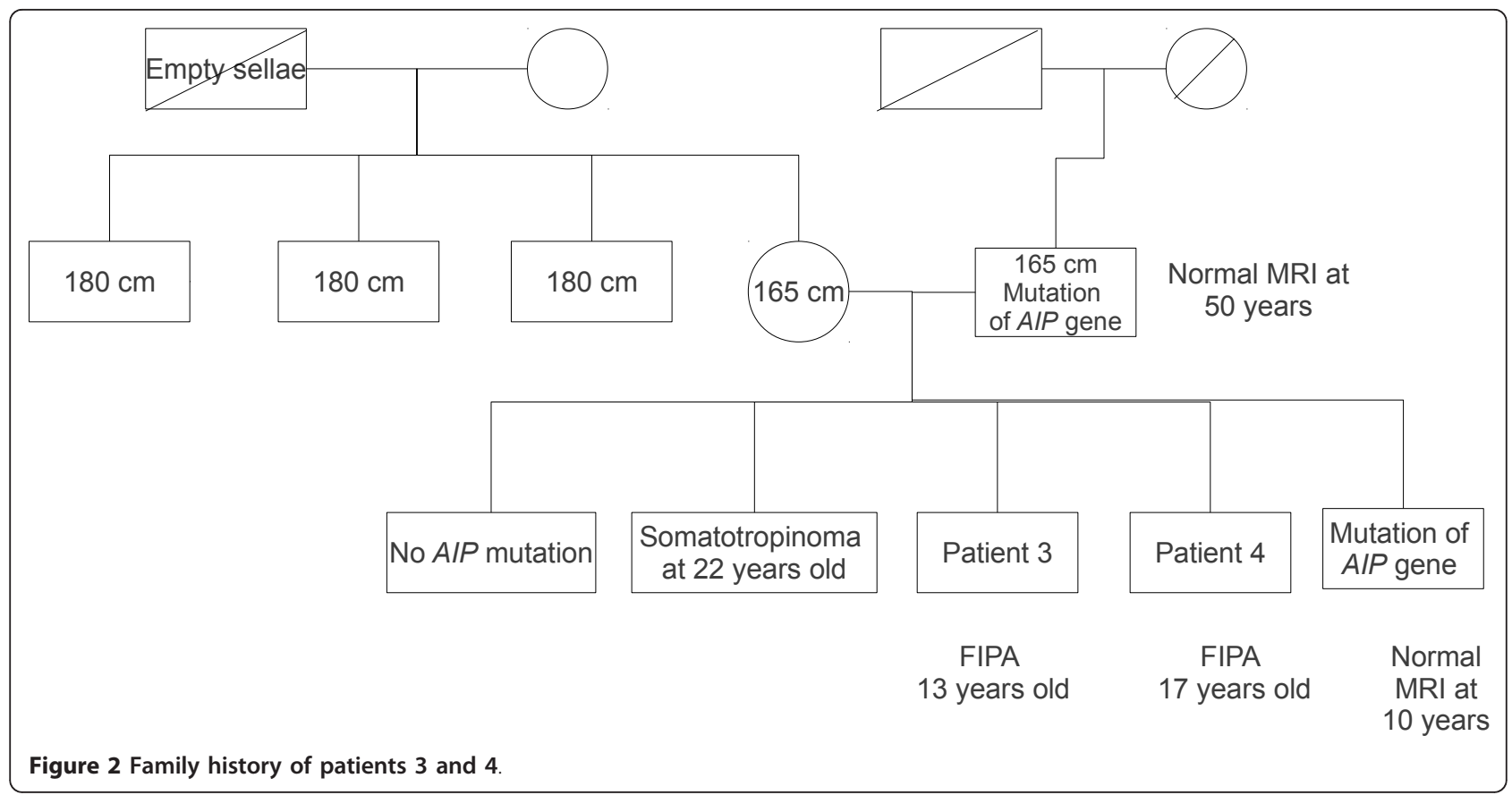

out of the three patients with a sporadic form (patients 5 and 7) who received only one type of therapy and two out of the four patients with a genetic form who received 2-3 types of therapy. Disease control was not achieved in patients 2 and 3 and 6 . A decrease in growth was observed when disease control was achieved (Figure 1).

\section{Discussion}

This series of paediatric patients is one of the largest series of somatotropinomas in children and gives new information on the therapeutic management of this disease. Recent epidemiological data have shown that the overall prevalence of pituitary adenomas was greater than previously estimated. It was measured at 94.4 and $77.6 /$ 100,000 inhabitants in the and Belgium [12] and United Kingdom [13] respectively, with somatotropinomas representing $13 \%$ and $11 \%$ of pituitary adenomas $[12,13]$. However, epidemiological data remain scarce in children. In accordance with our results, the literature reports a higher prevalence of $\mathrm{GH}$-secreting pituitary adenomas in boys than in girls [14-19]. This may be particularly true for genetic forms, and particularly in patients with AIPrelated pituitary adenomas. Daly et al. showed recently in a series of 96 AIP patients that $63.5 \%$ of them were male [10]. In contrast, in a series of 83 a priori sporadic somatotropinomas in adults and young patients, Tichomirowa et al. [20] observed that only $44.5 \%$ were male. However, an AIP mutation was identified in eleven cases (13.3\%), and eight of them were men.

The presentation of somatotropinoma in children differs according to whether the epiphyseal plate has fused or not. In the former situation, symptoms are similar to those seen in acromegalic adults [1]. In contrast, if somatotropinoma occurs prior to fusion of the epiphyseal plate, accelerated growth ensues with large size and extreme "gigantism" [1]. In our series, four patients had accelerated growth, two of whom had genetic forms of somatotropinoma. Daly et al. showed that in adult patients with AIP-related pituitary adenoma, gigantism was significantly more frequent than in controls (32\% vs. $6.5 \% ; \mathrm{p}<0.000001)$ [10]. In our series, whatever the age at diagnosis, the majority of patients presented with enlarged hands and feet.

Most pituitary adenomas in childhood are macroadenomas, and locally invasive tumours are frequently observed $[15,21]$; headaches and visual disturbances are, therefore, common $[15,21,22]$. In our series, five of seven patients presented with macroadenoma; of these patients, four had invasive macroadenomas, and three of these four had a genetic mutation (one MEN1, two AIP). This is consistent with the literature in adult patients, which reports larger tumours and a more aggressive presentation in patients with MEN1 versus without MEN1 (85\% vs. $42 \%$; p < 0.001 ) [4]. Recently, Daly et al. showed that the maximum tumour diameter was higher in patients with AIP-related somatotropinoma adenoma $(\mathrm{n}=75)$ than in age-matched AIP-negative patients $(\mathrm{n}=232)(22.5$ [7.0-60] vs. 16.0 [3.048] mm; p < 0.00026) [10].

Moreover, four studies reported a high proportion of genetic forms in children and young subjects [20,23-25]. Three of them [23-25] included, as did our study, seven cases of acromegaly in young subjects, with identification 
Table 2 Therapeutic intervention and follow-up in patients with somatotropinoma

\begin{tabular}{|c|c|c|c|c|c|c|c|c|c|}
\hline Patient & $\begin{array}{l}\text { Genetic } \\
\text { mutation }\end{array}$ & $\begin{array}{l}\text { IGF1 }(\mu \mathrm{g} / \mathrm{L}) \text { and } \\
\text { MRI at diagnosis }\end{array}$ & First-type therapy & Second-type therapy & $\begin{array}{l}\text { Third-type } \\
\text { therapy }\end{array}$ & $\begin{array}{l}\text { Fourth- } \\
\text { type } \\
\text { therapy }\end{array}$ & $\begin{array}{c}\text { Control } \\
\text { of } \\
\text { disease }\end{array}$ & $\begin{array}{l}\text { Last IGF1 } \\
(\mu \mathrm{g} / \mathrm{L}) \text { and } \\
\mathrm{MRI}\end{array}$ & $\begin{array}{c}\text { F-U } \\
\text { (Years) }\end{array}$ \\
\hline 1 & MAS & $\begin{array}{c}406 \text { (+3SD) } \\
\text { Hyperplasia } 565 \\
(+4 S D)\end{array}$ & Octreotide LAR 30 mg (monthly- 18 months) & + Cabergoline $1 \mathrm{mg} /$ week & $\begin{array}{l}\text { Pegvisomant } \\
20 \mathrm{mg} / \text { day }\end{array}$ & & C & $\begin{array}{c}333(-1 \text { SD) } \\
\text { NA }\end{array}$ & 7 \\
\hline 2 & MENI & $\begin{array}{c}\text { Invasive } \\
\text { Macroadenoma }(36 \\
\times 27 \times 28 \mathrm{~mm}) 1259 \\
(+4 \mathrm{SD})\end{array}$ & Trans-sphenoidal surgery & $\begin{array}{l}\text { Octreotide LAR } 30 \text { mg monthly (6 } \\
\text { months - growth of adenoma with } \\
\text { visual disturbance; } 3 \text { surgeries) }\end{array}$ & $\begin{array}{c}\text { + Cabergoline } \\
\text { with visual (1 } \\
\text { mg/week) }\end{array}$ & $\begin{array}{l}\text { Proton } \\
\text { therapy }\end{array}$ & NC & $\begin{array}{l}689(+2.5 \mathrm{SD}) \\
14 \times 10 \mathrm{~mm} \\
(-68 \%)\end{array}$ & 3 \\
\hline 3 & AIP & $\begin{array}{c}\text { Invasive } \\
\text { Macroadenoma }(21 \\
\times 26 \mathrm{~mm}) 997 \\
(+4 \mathrm{SD})\end{array}$ & Lanreotide LAR 90 mg monthly (6 months) & $\begin{array}{l}\text { Octreotide LAR } 30 \text { mg monthly + } \\
\text { cabergoline (1 mg/week) }\end{array}$ & $\begin{array}{l}\text { Transphenoidal } \\
\text { surgery }\end{array}$ & & NC & $\begin{array}{c}1184(+4 \mathrm{SD}) \\
10 \times 12 \times 9 \\
\mathrm{~mm}(-50 \%)\end{array}$ & 4 \\
\hline 4 & AIP & $\begin{array}{c}\text { Invasive } \\
\text { Macroadenoma }(16 \\
\times 21 \times 11 \mathrm{~mm}) 934 \\
(+4 \mathrm{SD})\end{array}$ & Lanreotide LAR 60 mg monthly (6 months) & Transphenoidal surgery & & & C & $\begin{array}{l}451 \text { (OSD) No } \\
\text { visible } \\
\text { adenoma }\end{array}$ & 6 \\
\hline 5 & $\begin{array}{c}\text { Negative } \\
\text { genetic analysis } \\
\text { (Carney, MEN1, } \\
\text { AlP) }\end{array}$ & $\begin{array}{l}\text { Non invasive } \\
\text { macroadenoma }(19 \\
\times 14 \times 20 \mathrm{~mm})\end{array}$ & Lanreotide LAR 60 mg monthly & & & & C & $\begin{array}{l}282(+1 S D) \\
\text { No visible } \\
\text { adenoma }\end{array}$ & 4 \\
\hline 6 & $\begin{array}{l}\text { Negative } \\
\text { genetic analysis } \\
\text { (MEN1, AlP) }\end{array}$ & $\begin{array}{l}777(+3 S D) \text { Invasive } \\
\text { macroadenoma }(26 \\
\times 26 \times 32 \mathrm{~mm})\end{array}$ & $\begin{array}{l}\text { Octreotide LAR } 30 \mathrm{mg} \text { monthly ( } 6 \text { months) } \\
\text { added to the previous Dopamine agonist } \\
\text { treatment (Cabergoline } 1,5 \mathrm{mg} / \mathrm{week} \text { ) }\end{array}$ & & & & NC & $\begin{array}{l}717(+3 S D) 34 \\
\times 21 \times 23 \\
\mathrm{~mm}(+6 \%)\end{array}$ & 2 \\
\hline 7 & $\begin{array}{c}\text { Negative } \\
\text { genetic analysis } \\
\text { (Carney, MEN1, } \\
\text { AIP) }\end{array}$ & $\begin{array}{l}574(+4 \mathrm{SD}) \\
\text { Microadenoma }(7,6 \\
\times 9 \times 7,5 \mathrm{~mm})\end{array}$ & Trans-sphenoidal surgery & & & & C & $\begin{array}{l}504(+1,5 \mathrm{SD}) \\
\text { No visible } \\
\text { adenoma }\end{array}$ & 4 \\
\hline
\end{tabular}




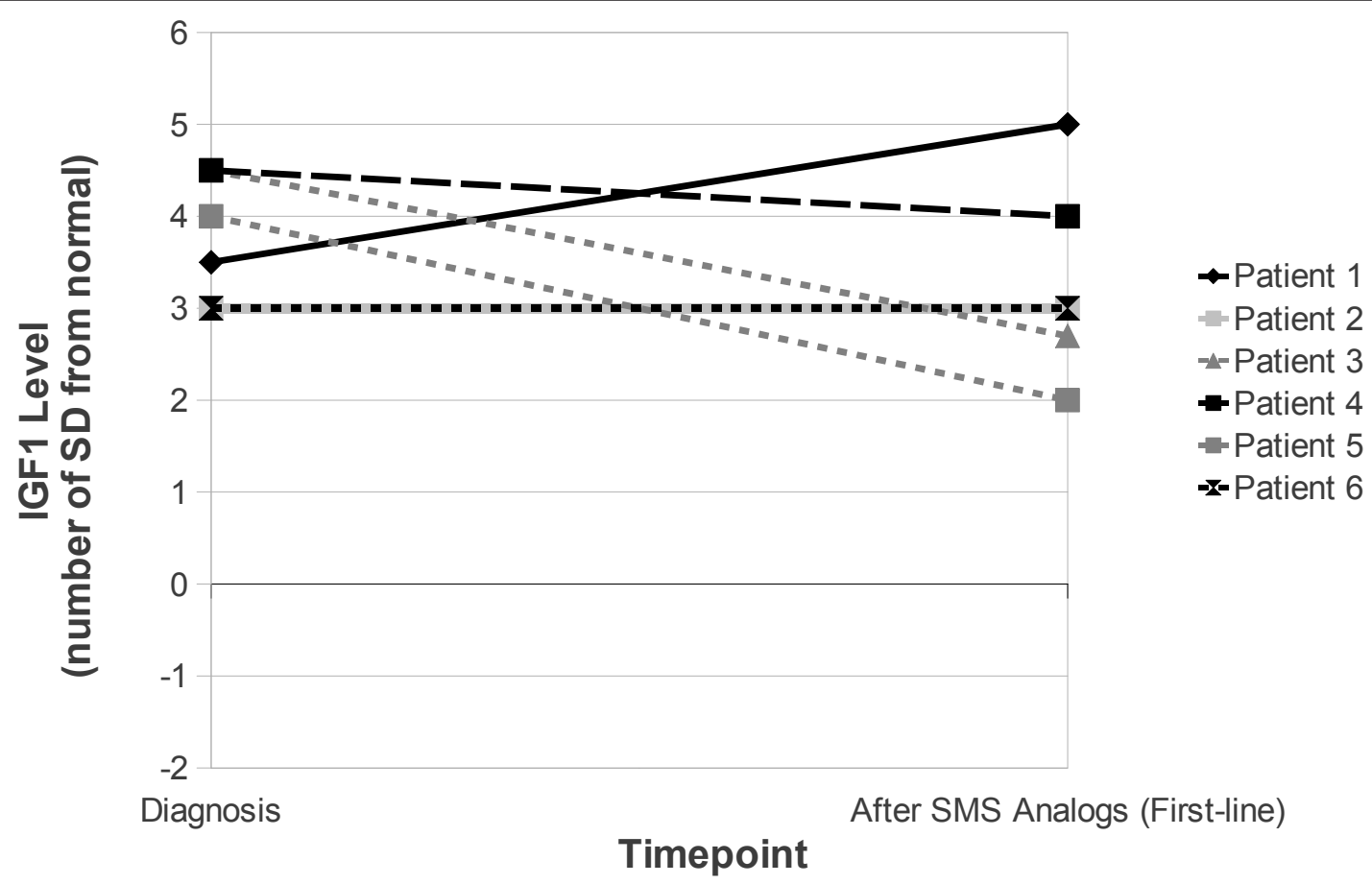

Figure 3 Change in insulin-like growth factor-1 levels during somatostatin (SMS) analogue therapy. Only patient 5, with intrasellar macroadenoma and a sporadic form, was controlled after first-line SMS analogues.

of a genetic form in 2-4 cases. In the fourth study, conducted by Tichomirowa et al., which included 39 patients with a pituitary macroadenoma diagnosed before 18 years, an AIP mutation was identified in $20.5 \%$ of cases [20].

In both adults and children, conventional treatment of somatotropinoma is transsphenoidal surgery $[15,18]$. In cases of intracavernous extension, or when surgery has been incomplete, pre- and/or post-operative SMS analogue treatment may be administered $[16,26]$ and has been shown to be safe in paediatric patients [14]. The GH receptor antagonist pegvisomant, or cabergoline in cases of somato-prolactinomas, can be used in acromegalic patients who have failed to respond to conventional treatment [14,27]. In our region, SMS analogues were effective in one of the six cases in whom they were used.

Cabergoline was administered to two patients in our series (both with genetic somatotropinoma) as second-type therapy in combination with SMS analogues. One of these patients required no further therapy, while the other (who had McCune-Albright syndrome) was switched to pegvisomant, which successfully reduced IGF-1 levels to -1 SD, consistent with the literature [28,29].

In adults, genetic forms of somatotropinoma are more difficult to control than sporadic forms. In a study of adult patients with pituitary adenomas, Verges et al. observed a normalization of pituitary hypersecretion in $90 \%$ of patients with sporadic adenomas and $42 \%$ of patients with MEN1 genetic alterations [4]. To date, little is known on the therapeutic response in children. Personnier et al., in a recent review, observed that GH control was obtained in $69 \%$ of cases in children [30]; in that analysis, genetic and sporadic forms were analyzed together. Accordingly, in another series of eleven sporadic paediatric pituitary adenomas, six were considered to be controlled by SMS analogues before and after surgery. Tumour size was reduced by $51.0 \%$ overall [14]. In contrast, Tichomirowa et al. [20] observed that, in a series of eleven paediatric and young patients with an AIPrelated somatotropinoma, at least two surgical interventions were necessary in $36.4 \%$ of cases, and that post-operative SMS analogue therapy was only effective in $11 \%$ of patients [20]. In our series, control was achieved in two out of the three patients with a sporadic somatotropinoma after one type of therapy. In contrast, all patients with genetic somatotropinoma required two $(n=2)$ or three $(n=2)$ types of therapy, and only two out of four such patients were cured. Three patients received SMS analogues as first-type therapy; these were followed by cabergoline, pegvisomant or transsphenoidal surgery. In the fourth patient, transsphenoidal surgery was ineffective as first-type therapy, and IGF-1 levels remained +2 SD even after subsequent SMS analogues and radiotherapy. These findings suggest that SMS analogues have little efficacy in patients with genetic somatotropinoma and that, as reported in adults [4], hormonal control is more difficult to achieve in patients with genetic somatotropinomas than in patients with sporadic forms. 


\section{Conclusions}

Somatotropinomas in children and adolescents are rare and more aggressive than those seen in adults. In this small series of patients, genetic somatotropinomas were more invasive than sporadic somatotropinomas. Our data suggest that SMS analogues, while effective in sporadic somatotropinoma, are less effective in genetic somatotropinoma. Further research on the incidence and types of genetic mutations in children and adolescents with somatotropinoma is necessary to increase our understanding of the disease. In addition, studies of different therapeutic options in genetic somatotropinoma would provide more information about why SMS analogues are less effective in these patients, and allow for the development of new treatment strategies in this setting.

\section{Acknowledgements}

This study was supported by Pfizer. Medical writing assistance was provided by Claire Byrne of inscience Communications (a Wolters Kluwer business), and funded by Pfizer. Written consent for publication was obtained from the patients or their relatives.

\section{Author details}

'Fédération d'Endocrinologie du Pôle Est, Groupement Hospitalier Lyon Est, 69677, Bron, Cedex, France. ${ }^{2}$ Service d'Endocrinologie Pédiatrique; Groupement Hospitalier Lyon Est, 69677, Bron, Cedex, France. ${ }^{3}$ Service de Pédiatrie, CHU La Tronche, BP2178, 38243, Grenoble, Cedex 9, France. ${ }^{4}$ Service de Pédiatrie, Hôpital Nord, 42055, Saint-Etienne, Cedex 2, France. ${ }^{5}$ Service d'Endocrinologie Moléculaire et Maladies Rares, Centre de Biologie Est, Hospices Civils de Lyon, Bron, Cedex, France.

\section{Authors' contributions}

$C R-R, C D, P B$ : each of them provided data from a patient. YM measured and analyzed IGF-1 and prolactin levels. FB-C provided data from three patients and managed this work. MN provided data from a patient and managed this work. CN collected and analyzed all data and wrote this paper with the assistance of Claire Byrne of inScience Communications (a Wolters Kluwer business). All authors read and approved the final manuscript.

\section{Competing interests}

The authors declare that they have no competing interests.

Received: 27 April 2011 Accepted: 24 October 2011

Published: 24 October 2011

\section{References}

1. Keil MF, Stratakis CA: Pituitary tumors in childhood: update of diagnosis, treatment and molecular genetics. Expert Rev Neurother 2008, 8:563-574.

2. Horvath A, Stratakis CA: Clinical and molecular genetics of acromegaly: MEN1, Carney complex, McCune-Albright syndrome, familial acromegaly and genetic defects in sporadic tumors. Rev Endocr Metab Disord 2008, 9:1-11.

3. Lamberts SW, van der Lely AJ, de Herder WW: Transsphenoidal selective adenomectomy is the treatment of choice in patients with Cushing's disease. Considerations concerning preoperative medical treatment and the long-term follow-up. J Clin Endocrinol Metab 1995, 80:3111-3113.

4. Vergès $B$, Boureille $F$, Goudet $P$, Murat $A$, Beckers $A$, Sassolas $G$, Cougard $P$, Chambe B, Montvernay C, Calender A: Pituitary disease in MEN type 1 (MEN1): data from the France-Belgium MEN1 multicenter study. $J$ Clin Endocrinol Metab 2002, 87:457-465.

5. Trump D, Farren B, Wooding C, Pang JT, Besser GM, Buchanan KD, Edwards CR, Heath DA, Jackson CE, Jansen S, Lips K, Monson JP. O'Halloran D, Sampson J, Shalet SM, Wheeler MH, Zink A, Thakker RV: Clinical studies of multiple endocrine neoplasia type 1 (MEN1). QJM 1996, 89:653-669.
6. Stergiopoulos SG, Abu-Asab MS, Tsokos M, Stratakis CA: Pituitary pathology in Carney complex patients. Pituitary 2004, 7:73-82.

7. Albright F, Butler AM, Hampton AO, Smith P: Syndrome characterized by osteitis fibrosa disseminata, areas of pigmentation, and endocrine dysfunction, with precocious puberty in females: report of 5 cases. $N$ Engl J Med 1937, 216.

8. Vierimaa O, Georgitsi M, Lehtonen R, Vahteristo P, Kokko A, Raitila A Tuppurainen K, Ebeling TML, Salmela PI, Paschke R, Gündogdu S, De Menis E, Mäkinen MJ, Launonen V, Karhu A, Aaltonen LA: Pituitary adenoma predisposition caused by germline mutations in the AIP gene. Science 2006, 312:1228-1230.

9. Daly AF, Jaffrain-Rea ML, Ciccarelli A, Valdes-Socin H, Rohmer V, Tamburrano G, Borson-Chazot C, Estour B, Ciccarelli E, Brue T, Ferolla P, Emy P, Colao A, De Menis E, Lecomte P, Penfornis F, Delemer B, Bertherat J, Wémeau JL, De Herder W, Archambeaud F, Stevenaert A, Calender A, Murat A, Cavagnini F, Beckers A: Clinical characterization of familial isolated pituitary adenomas. J Clin Endocrinol Metab 2006, 91:3316-3323.

10. Daly AF, Tichomirowa MA, Petrossians P, Heliövaara E, Jaffrain-Rea ML, Barlier A, Naves LA, Ebeling T, Karhu A, Raappana A, Cazabat L, De Menis E, Montañana CF, Raverot G, Weil RJ, Sane T, Maiter D, Neggers S, Yaneva M, Tabarin A, Verrua E, Eloranta E, Murat A, Vierimaa O, Salmela PI, Emy P, Toledo RA, Sabaté MI, Villa C, Popelier M, Salvatori R, Jennings J, Longás AF, Labarta Aizpún Jl, Georgitsi M, Paschke R, Ronchi C, Valimaki M, Saloranta C, De Herder W, Cozzi R, Guitelman M, Magri F, Lagonigro MS, Halaby G, Corman V, Hagelstein MT, Vanbellinghen JF, Barra GB, Gimenez-Roqueplo AP, Cameron FJ, Borson-Chazot F, Holdaway I, Toledo SPA, Stalla GK, Spada A, Zacharieva S, Bertherat J, Brue T, Bours V, Chanson P, Aaltonen LA, Beckers A: Clinical characteristics and therapeutic responses in patients with germline AIP mutations and pituitary adenomas: an international collaborative study. J Clin Endocrinol Metab 2010, 95:E373-383.

11. Hardy J, Vezina JL: Transsphenoidal neurosurgery of intracranial neoplasm. Adv Neurol 1976, 15:261-273.

12. Daly AF, Rixhon M, Adam C, Dempegioti A, Tichomirowa MA, Beckers A: High prevalence of pituitary adenomas: a cross-sectional study in the province of Liege, Belgium. J Clin Endocrinol Metab 2006, 91:4769-4775.

13. Fernandez A, Karavitaki N, Wass JAH: Prevalence of pituitary adenomas: a community-based, cross-sectional study in Banbury (Oxfordshire, UK). Clin Endocrinol (Oxf) 2010, 72:377-382.

14. Colao A, Pivonello R, Di Somma C, Tauchmanovà L, Savastano S, Lombardi G: Growth hormone excess with onset in adolescence: clinical appearance and long-term treatment outcome. Clin Endocrinol (Oxf) 2007, 66:714-722.

15. Abe T, Tara LA, Lüdecke DK: Growth hormone-secreting pituitary adenomas in childhood and adolescence: features and results of transnasal surgery. Neurosurgery 1999, 45:1-10

16. Cannavò S, Venturino M, Curtò L, De Menis E, D'Arrigo C, Tita P, Billeci D, Trimarchi F: Clinical presentation and outcome of pituitary adenomas in teenagers. Clin Endocrinol (Oxf) 2003, 58:519-527.

17. De Menis E, Visentin A, Billeci D, Tramontin P, Agostini S, Marton E, Conte N: Pituitary adenomas in childhood and adolescence. Clinical analysis of 10 cases. J Endocrinol Invest 2001, 24:92-97.

18. Dyer EH, Civit T, Visot A, Delalande O, Derome P: Transsphenoidal surgery for pituitary adenomas in children. Neurosurgery 1994, 34:207-212, discussion 212

19. Kunwar S, Wilson CB: Pediatric pituitary adenomas. J Clin Endocrinol Metab 1999, 84:4385-4389.

20. Tichomirowa MA, Barlier A, Daly AF, Jaffrain-Rea ML, Ronchi CL, Yaneva M, Urban JD, Petrossians P, Elenkova AP, Tabarin A, Desailloud R, Maiter D, Schürmeyer T, Cozzi R, Theodoropoulou M, Sievers C, Bernabeu I, Naves LA, Chabre O, Fajardo Montañana C, Hana V, Halaby G, Delemer B, Labarta Jl, Sonnet E, Ferrandez A, Hagelstein MT, Caron P, Stalla GK, Bours V, Zacharieva S, Spada A, Brue T, Beckers A: High Prevalence of AIP Gene Mutations Following Focused Screening in Young Patients with Sporadic Pituitary Macroadenomas. Eur J Endocrinol 2011.

21. Pandey P, Ojha BK, Mahapatra AK: Pediatric pituitary adenoma: a series of 42 patients. J Clin Neurosci 2005, 12:124-127.

22. Katavetin P, Cheunsuchon P, Swearingen B, Hedley-Whyte ET, Misra M, Levitsky LL: Review: Pituitary adenomas in children and adolescents. Pediatr Endocrinol Metab 2010, 23:427-431.

23. Georgitsi M, De Menis E, Cannavò S, Mäkinen MJ, Tuppurainen $K$, Pauletto P, Curtò L, Weil RJ, Paschke R, Zielinski G, Wasik A, Lubinski J, 
Vahteristo P, Karhu A, Aaltonen LA: Aryl hydrocarbon receptor interacting protein (AIP) gene mutation analysis in children and adolescents with sporadic pituitary adenomas. Clin Endocrinol (Oxf) 2008, 69:621-627.

24. Cazabat L, Bouligand J, Chanson P: AIP mutation in pituitary adenomas. N Engl J Med 2011, 364:1973-1974, author reply 1974-1975.

25. Stratakis CA, Tichomirowa MA, Boikos S, Azevedo MF, Lodish M, Martari M, Verma S, Daly AF, Raygada M, Keil MF, Papademetriou J, Drori-Herishanu L, Horvath A, Tsang KM, Nesterova M, Franklin S, Vanbellinghen JF, Bours V, Salvatori $R$, Beckers A: The role of germline AIP, MEN1, PRKAR1A, CDKN1B and CDKN2C mutations in a large cohort of children and adolescents with pituitary adenomas. Clin Genet 2010, 78:457-463.

26. Z-gang Mao, Y-hong Zhu, H-liang Tang, D-yuan Wang, Zhou J, D-sheng He, Lan H, B-ning Luo, H-jun Wang: Preoperative lanreotide treatment in acromegalic patients with macroadenomas increases short-term postoperative cure rates: a prospective, randomised trial. Eur J Endocrinol 2010, 162:661-666

27. van der Lely AJ, Muller A, Janssen JA, Davis RJ, Zib KA, Scarlett JA, Lamberts SW: Control of tumor size and disease activity during cotreatment with octreotide and the growth hormone receptor antagonist pegvisomant in an acromegalic patient. J Clin Endocrinol Metab 2001, 86:478-481.

28. Akintoye SO, Kelly MH, Brillante B, Cherman N, Turner S, Butman JA, Robey PG, Collins MT: Pegvisomant for the treatment of gsp-mediated growth hormone excess in patients with McCune-Albright syndrome. J Clin Endocrinol Metab 2006, 91:2960-2966.

29. Galland F, Kamenicky P, Affres H, Reznik Y, Pontvert D, Le Bouc Y, Young J, Chanson P: McCune-Albright syndrome and acromegaly: effects of hypothalamopituitary radiotherapy and/or pegvisomant in somatostatin analog-resistant patients. J Clin Endocrinol Metab 2006, 91:4957-4961.

30. Personnier C, Cazabat L, Bertherat J, Gaillard S, Souberbielle JC, Habrand JL, Dufour C, Clauser E, SainteRose C, Polak M: Clinical features and treatment of pediatric somatotropinoma: case study of an aggressive tumor due to a new AIP mutation and extensive literature review. Horm Res Paediatr 2011, 75(6):392-402.

doi:10.1186/1750-1172-6-67

Cite this article as: Nozières et al: Sporadic and genetic forms of paediatric somatotropinoma: a retrospective analysis of seven cases and a review of the literature. Orphanet Journal of Rare Diseases 2011 6:67.

\section{Submit your next manuscript to BioMed Central and take full advantage of:}

- Convenient online submission

- Thorough peer review

- No space constraints or color figure charges

- Immediate publication on acceptance

- Inclusion in PubMed, CAS, Scopus and Google Scholar

- Research which is freely available for redistribution

Submit your manuscript at www.biomedcentral.com/submit 